\title{
An Assessment of the Barriers to Social Dimension of SSCM Practice Implementation Using Fuzzy DEMATEL Approach: A Case from Turkey
}

\author{
Gözde KOCA ${ }^{1}$ \\ Kaliyan MATHIYAZHAGAN²
}

https://orcid.org/0000-0001-6847-6812
https://orcid.org/0000-0002-2340-7394

\begin{abstract}
The Sustainable Supply Chain Management (SSCM) concept, which establishes a balance between economic, social and environmental dimensions, provides an extremely important conceptual framework for companies. Although not all of these dimensions have the same significance, researchers mostly focus on economic and environmental aspects. However, it is very difficult to apply the social dimension in the adoption of SSCM due to the barriers encountered in SSCM. Based on this, this paper aims to analyze the social barriers and identify the relationship between the barriers with the help of Fuzzy DEMATEL. In this study, thirteen barriers to analysis have been determined. As a result of the analysis, the first major barrier is defined as "Stakeholders' Negative Influence (B12)", the second barrier as "Lack of Culture without Engagement and Support (B8)", and the third one as "Ignoring the Rights of Stakeholders (B13)". The barrier having the most impact on other barriers was determined as "Lack of State Support" and the barrier which was affected most by other barriers is "Low price demand of the community (B6)".
\end{abstract}

Keywords: Sustainable Supply Chain Management (SSCM); Social Dimensions; Barriers; Fuzziness; DEMATEL; Turkey

Jel Codes: Q01, C44, D81, D91.

\section{INTRODUCTION}

In the last decade, the concept of sustainability began to emerge in the discipline of Supply Chain Management (SCM) in the literature. Sustainable Supply Chain Management (SSCM) is a system that manages the material flow, information flow, money flow and the relationship among all companies in the chain. This chain also includes environmental, economic and social dimensions of sustainability (Seuring and Müller, 2008). True sustainability is the point where these three structures take place at the same time. However, these dimensions do not have the same importance (Smith, 1995). Studies led to a decrease in studies on the social dimension, as it focuses more on economic and environmental dimensions. Social sustainability is the human aspect of sustainability.
Issues of social dimensions are related to the quality of life and it allows decision-makers to take the potential social consequences of their decisions into account. Such decision-makers should take into account that everyone has the opportunity to live a full existence in intellectual, emotional, spiritual and physical terms (Hussain et al., 2018, Silvis, 2012). During the adoption of the social dimension of the sustainable supply chain, it is inevitable to encounter some barriers. Barriers to social dimensions in the SSCM include lack of government support, lack of guidelines, the absence of society, lack of market demand, less business-friendly policies, pressure for lower prices. However, it will be impossible to eliminate all barriers at the same time. For this reason, industries should identify the barriers that should be initially removed in the early stages of the adoption

\footnotetext{
${ }^{1}$ Assistant Professor, Department of Bussiness Administration, FEAS, Bilecik Seyh Edebali University, Bilecik, Turkey gozde.koca@bilecik.edu.tr

${ }^{2}$ Associate Professor, Department of Mechanical Engineering, Amity School of Engg., \& Tech (ASET), Amity University, Sector 125, Noida - 201313, Uttar Pradesh, India. madii1984@yahoo.com
} 
of the social dimension of the SSCM. Especially, the barriers to the social dimension of the SSCM needed to be identified to determine the priorities to eliminate these barriers because there are not enough studies on the social dimension of the SSCM in Turkey.

Social dimension implementations in the SSCM emerged as an important research area. Barriers that play a key role in the realization of social dimension practices in the SSCM restrict the better corporate performance of an organization. Therefore, it needs to be investigated. This observation encouraged the authors to do this research. The main objectives of this research are:(i) To review the impact of social dimensions in SSCM; (ii) To identify the list of barriers to social dimensions in SSCM in the literature and to conduct discussion with experts; (ii) To identify the influential barrier with the help of the Fuzzy DEMATEL approach. The structure of this paper is organized as follows: Barriers to social dimensions in the SSCM have been expressed as a result of the literature review in Section 2. The summary of the case study details is in Section 3. Fuzzy DEMATEL analysis is discussed in Section 4. Section 5 includes the design of the research. Results and discussion are presented in Section 6. Section 7 emphasizes the results and the scope for future work.

\section{LITERATURE REVIEW}

This section explores the research gap for the selected study with the help of recent literature on SSCM practices and the impact of social dimensions along with barriers to the implementation of the SSCM concept.

\subsection{Sustainable Supply Chain Management: Social Dimensions}

Sustainability has become an important part of the business world. Sustainability is based on the tripartite structure (environmental dimension, economic dimension, and social dimension) which implies the necessity of goals to be balanced when competing in the global economy (Kleindorfer et al., 2005). True sustainability is the point where these three structures take place at the same time (Carter and Rogers, 2008). The social dimension of the SSCM is known, but it is less important than expected (Ashby et al., 2012). Because the economic and environmental dimensions of sustainability are examined more extensively than the social dimension. The social dimension is defined as the most difficult and uncertain concept in sustainability (Khan et al., 2018). However, the importance attached to the social dimen- sion has been increasing in the last few years. According to Mani et al., (2016) the social dimension consists of many basic subjects such as equality, security, human rights, philanthropy, ethics, health, and welfare. Thus, communities and business organizations that do not respond to the wishes of global transformation are increasingly concerned with the acceptance of the social dimension (Fontaine et al., 2006).

\subsection{Barriers to Social Dimensions in SSCM}

Studies on SSCM generally focus on the environmental dimension and the economic dimension. SSCM is available in field studies as a whole without dividing the dimensions. Studies on the social dimension of the SSCM are drivers, criteria, motivators, and indicators of the social dimension (Ahmadi et al., 2017, Morais and Silvestre, 2018, Khan et al., 2018, Popovic et al., 2018). Hussian et al (2018) conducted one of the studies that focus on the barriers to the social dimension of the SSCM. In the paper; the barriers, motivations, and providers of social sustainability in the health sector were investigated. Social barriers in the health sector are defined as resource constraints, policies, high competition, cost, low commitment, and perception. Kamali et al. (2018) identified the most important and effective social sustainability issues in the biofuel sector by following the survey method. The results showed that the issues related to the subject were extremely important in general. Moktadir et al (2018) modeled the relationship between barriers in the SSCM in the leather industry. As a result, nine barriers were identified as "cause" and eleven barriers were identified as "influenced". Low awareness of local customers in green products and lack of responsibility for senior management have a high significance in the causal group. Al Zaabi et al. (2013) determined the relationship between the barriers encountered in the implementation of SSCM and identified the most effective barriers through the interpretative structural modeling and the proposed barrier list. In this study, thirteen barriers were addressed in the current comprehensive literature. The barriers were divided into groups according to their effects. The most dominant barriers include the complex design to reduce resource and energy consumption, eco-friendly packaging cost, lack of clarity about sustainability. Narayan et al. (2018) identified, modeled, analyzed, and prioritized barriers to the implementation of sustainable practices in the rubber industry in Kerala, a state located in South India. Lack of government initiatives and lack of benchmark are identified as the biggest barriers. 


\subsection{Review Result}

The awareness, adoption, and identification of the barriers to the social dimension of the SSCM are not as effective as in other dimensions. In particular, there are no studies on the barriers to the social dimension of SSCM in Turkey. Most of the studies focus on the barriers to Green Supply Chain Management (GSCM) in the environmental dimension of SSCM in Turkey. Behdioglu and Koca (2017) investigated the barriers encountered during the GSCM initiatives in the Turkish automotive industry. After all, the most important barriers were found to be implementation costs, lack of information, insufficient environmental awareness.

Kiris and Borekci (2018) identified drivers and barriers in sustainable port systems and presented a conceptual analysis by examining these factors in line with the triple bottom line approach, which includes a combination of economic, social and environmental values. In the results of this study; drivers focused on environmental sustainability issues and barriers focused on economic sustainability issues were observed in the sustainable port literature. Koska et al. (2016) evaluated the GSCM barriers at a paper factory in Turkey with AHP. The overall result achieved by the analyzes is the most important factor that can hamper the green supply chain applications of the enterprise among finance, technology, information and outsourcing factors. Lots of research focuses on analyzing the enablers and barriers or challenging factors for SSCM practices adoption. However, less research on barriers for social dimension adoption in SSCM practices and industries are struggling to find which factors (barriers) are acting as an influential role. This is the main motivation behind this study. There is a literature gap in determining social barriers to the implementation of SSCM. This paper addresses this gap with a two-stage research approach.

Stage 1: A literature review was conducted to determine the social barriers in SSCM implementations. This literature review was done by searching the keyword "barriers of the sustainable supply chain" in various databases. Thirteen social barriers were identified with this literature review.

Stage 2: Fuzzy DEMATEL method followed in determining these thirteen social barriers weights and the relationship between these thirteen social barriers. In this way, priority barriers were identified and the most important barriers were revealed. Also, these barriers have been examined as cause and effect.

The rest of the paper continued with Section 3 Case Illustration, where a literature review was introduced to social barriers and Section 4 Solution Methodology, which shows how the solution was made.

\section{CASE ILLUSTRATION}

The "Sustainability" concept in Turkey can be observed as more companies are adopting the institutional structure operation on an international level. Since sustainability reporting on the SSCM is not mandatory and few companies are preparing this report, few studies have been carried out (Ozcelik and Ozturk, 2014). The studies conducted in Turkey focus more on the economic and environmental dimension. In particular, there are no studies on the barriers to the social dimension in Turkey. Further improvements on the concept of the social dimension in Turkey is a need to identify the priority barriers to be made. The ranking of the barriers to the social dimension encountered in this study was carried out in Turkey. Thirteen barriers collected from the literature are given in Table 1. To determine the most important of these barriers, five academic staff and five sector experts were taken into consideration. Evaluations were performed with consensus. Therefore, this study offers a new approach to Turkey's perspective to understand the barriers to the implementation of the social dimension of SSCM. 
Table 1: Barriers to The Social Dimension in Sustainability Supply Chain Practice İmplementation

\begin{tabular}{|c|c|c|}
\hline Barriers & Short description & References \\
\hline Lack of government support (B1) & $\begin{array}{l}\text { The government does not provide adequate } \\
\text { support for sustainable activities. }\end{array}$ & $\begin{array}{l}\text { Govindan et al. (2013), Prakash } \\
\text { and Barua (2015); }\end{array}$ \\
\hline $\begin{array}{l}\text { Lack of guidelines to adopt the social } \\
\text { dimensions in SSCM practices for } \\
\text { industries (B2) }\end{array}$ & $\begin{array}{l}\text { There is a lack of clarity about the guidelines for } \\
\text { the social dimension implementation of SSCM. }\end{array}$ & Govindan et al. (2013) \\
\hline Lack of community pressure (B3) & $\begin{array}{l}\text { The community has low pressure on NGOs and } \\
\text { environmental authorities }\end{array}$ & $\begin{array}{l}\text { Govindan et al. (2014a, 2014b), } \\
\text { Wang et al. (2015) }\end{array}$ \\
\hline $\begin{array}{l}\text { Low market demand for sustainable } \\
\text { products (B4) }\end{array}$ & $\begin{array}{l}\text { The demand remains low because people do } \\
\text { not adopt the use of sustainable products. }\end{array}$ & Lin et al. (2013) \\
\hline $\begin{array}{l}\text { There are few business-friendly } \\
\text { policies (B5). }\end{array}$ & $\begin{array}{l}\text { The lack of adequate policies to support } \\
\text { sustainability. }\end{array}$ & Moktadir et al. (2018) \\
\hline $\begin{array}{l}\text { Low price demand of the community } \\
\text { (B6) }\end{array}$ & $\begin{array}{l}\text { Nowadays, due to the high price of sustainable } \\
\text { products, the demand for them is low. }\end{array}$ & $\begin{array}{l}\text { Koho et al. (2011), Al Khidir and } \\
\text { Zailani (2009) }\end{array}$ \\
\hline Lack of infrastructure(B7) & $\begin{array}{l}\text { Lack of adequate infrastructure, such as } \\
\text { technology, to ensure sustainability as a country. }\end{array}$ & Silvestre, 2015, Lam, 2011 \\
\hline $\begin{array}{l}\text { Lack of culture without engagement } \\
\text { and support (B8) }\end{array}$ & $\begin{array}{l}\text { Companies do not engage in sustainability } \\
\text { among themselves and do not support each } \\
\text { other. }\end{array}$ & Lund-Thomsen et al., 2012 \\
\hline Corruption and mock compliance (B9) & $\begin{array}{l}\text { Corruption and false relationships among } \\
\text { companies, certification bodies, and government } \\
\text { in the country. }\end{array}$ & Silvestre, 2015 \\
\hline $\begin{array}{l}\text { Disruptions in the operation of the } \\
\text { work health and safety management } \\
\text { system(B10) }\end{array}$ & $\begin{array}{l}\text { This is related to the health and safety of workers } \\
\text { and the welfare of the workplace. }\end{array}$ & $\begin{array}{l}\text { Azadnia et al. (2015), Bai and } \\
\text { Sarkis (2010),.Luthra et al. } \\
(2017 a, b) \text {. }\end{array}$ \\
\hline $\begin{array}{l}\text { The interests and rights of employees } \\
\text { are ignored (B11). }\end{array}$ & $\begin{array}{l}\text { Sustainable employment issues such as } \\
\text { employee rights and interests are not taken into } \\
\text { consideration. }\end{array}$ & $\begin{array}{l}\text { Amindoust et al. (2012), Luthra } \\
\text { et al. (2017a), Kuo et al. (2010). }\end{array}$ \\
\hline Stakeholders' negative influence (B12) & $\begin{array}{l}\text { The fact that a company's stakeholders are not } \\
\text { concerned about the sustainability effects on the } \\
\text { chain. }\end{array}$ & $\begin{array}{l}\text { Ahmadi et al. (2017), Presley et } \\
\text { al. (2007); Govindan et al. (2013). }\end{array}$ \\
\hline $\begin{array}{l}\text { Ignoring the rights of stakeholders } \\
\text { (B13). }\end{array}$ & $\begin{array}{l}\text { The rights of all stakeholders involved in the } \\
\text { sustainable supply chain are ignored. }\end{array}$ & $\begin{array}{l}\text { Kuo et al. (2010), Amindoust et } \\
\text { al. (2012), Luthra et al. (2017a, b). }\end{array}$ \\
\hline
\end{tabular}




\section{SOLUTION METHODOLOGY}

Fuzzy DEMATEL which is the method used is examined in this section. The flowchart of the Fuzzy DEMATEL methodology is given in Figure 1 below.

Experts group for barrier analysis for the social dimension implementation

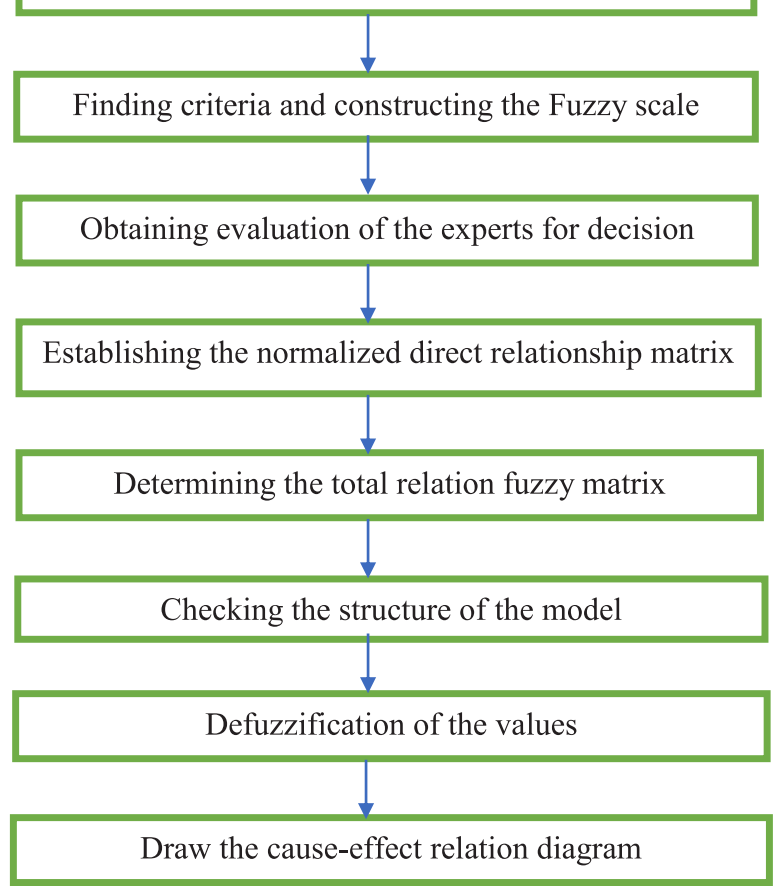

Figure 1: The Flowchart Of Fuzzy DEMATEL Methodology

\subsection{DEMATEL}

The Battelle Memorial Institute conducted a DEMATEL method project through its Geneva Research Centre (Gabus \& Fontela, 1972, 1973). The original DEMATEL was aimed at the fragmented and antagonistic phenomena of world societies and searched for integrated solutions. The Decision Making Experiment and Evaluation Laboratory (DEMATEL) approach was established in 1973 by Geneva to solve complex problems (Muhammad \& Cavus, 2017; Shieh et al., 2010). This method is used to transform the relationship between the causes and effects of the barrier into a justified model of the chosen system (Dalalah et al., 2011). DEMATEL is an expanded approach to construct and analyze a structural model to analyze the impact factors between complex criteria. However, decision-making in a fuzzy environment is difficult to segment into complex factors (Wu and Lee, 2007). This study uses a fuzzy DEMATEL method to obtain a more accurate analysis.
DEMATEL can reduce the number of criteria at the same time to assess factor effectiveness; companies can improve the effectiveness of certain factors based on the impact map. For this reason, DEMATEL evaluates supplier performance to increase performance in SCM supplier selection and to find the main factor for providing decision information. To create a structural model of the strategy map, decisions of managers to decide the relationship between the objectives of the organization are generally based on group decision-making procedures. Because of the humanistic judgmental characteristics of the strategy map, the boards of directors must give their preferences and importance to some relations between the real net values that are interestingly insufficient in the real world and the strategic goals they choose.

\subsection{Fuzzy DEMATEL}

In this model, fuzzy logic and DEMATEL are combined in a decision model but applied independently. This model first uses fuzzy sets to address experts' uncertainty decisions and assessments of impact levels between factors then convert fuzzy numbers to net values for the group direct impact matrix and perform the classical DEMATEL procedure.

The Fuzzy DEMATEL steps are given as follows (Tseng, 2009).

Step 1: Select an expert group: This step refers to experts who have sufficient knowledge and experience of the problem to obtain results.

Step 2: Identify the factors and create the fuzzy scale: At this stage, important factors are determined to accurately analyze and evaluate. Then, a linguistic variable is used according to five fuzzy scales (no effect, very low impact, low impact, high effect, and very high impact). Then, the corresponding triangular fuzzy members are identified.

Step 3: Take the assessment of group decision-makers: Pairwise comparison is obtained in terms of linguistic variables. Also, fuzzy assessments are collected as a defuzzified and crisp value. As a result, the initial direct relationship fuzzy matrix (Ẽ) is constructed (Equality (1)- Equality (2)).

$$
\begin{aligned}
& \tilde{\mathrm{E}}=\left[\begin{array}{ccc}
0 & \cdots & \tilde{\mathrm{e}}_{1 \mathrm{n}} \\
\vdots & \ddots & \vdots \\
\tilde{\mathrm{e}}_{1 \mathrm{n}} & \cdots & 0
\end{array}\right] \\
& \tilde{\mathrm{e}}_{\mathrm{ij}}=\left(\mathrm{l}_{\mathrm{ij}}, \mathrm{m}_{\mathrm{ij}}, \mathrm{u}_{\mathrm{ij}}\right)
\end{aligned}
$$


Step 4: Create a normalized direct-relation fuzzy matrix: In the presence of the initial direct relationship matrix, a normalized direct relationship fuzzy matrix is generated. For achieving that, first of all, it is considered $\tilde{\beta}$ and $\gamma$ as triangular fuzzy numbers. The below calculation is carried out respectively (Equality (3) - Equality (4)).

$$
\begin{aligned}
& \widetilde{\beta}=\sum \tilde{\mathrm{e}}_{\mathrm{ij}}=\left(\sum_{\mathrm{j}=1}^{\mathrm{n}} \mathrm{l}_{\mathrm{ij}}, \sum_{\mathrm{j}=1}^{\mathrm{n}} \mathrm{m}_{\mathrm{ij}}, \sum_{\mathrm{j}=1}^{\mathrm{n}} \mathrm{u}_{\mathrm{ij}}\right) \\
& \gamma=\max \left(\sum_{\mathrm{j}=1}^{\mathrm{n}} \mathrm{u}_{\mathrm{ij}}\right)
\end{aligned}
$$

Furthermore, the linear scale transformation is implemented to convert the factors into corresponding scales. The normalized direct-relation fuzzy matrix $(\widetilde{F})$ of group decision-makers can be shown as below (Equality (5) - Equality (6)).

$$
\widetilde{F}=\left[\begin{array}{ccc}
\tilde{f}_{11} & \cdots & \widetilde{f}_{1 \mathrm{n}} \\
\vdots & \ddots & \vdots \\
\widetilde{f}_{\mathrm{n} 1} & \cdots & \widetilde{f}_{\mathrm{nn}}
\end{array}\right]
$$

Where $\widetilde{f}_{\mathrm{ij}}=\frac{\tilde{\mathrm{e}}_{\mathrm{ij}}}{\gamma}=\left(\frac{\tilde{\mathrm{e}}_{\mathrm{ij}}}{\gamma}, \frac{\tilde{\mathrm{e}}_{\mathrm{ij}}}{\gamma}, \frac{\tilde{\mathrm{e}}_{\mathrm{ij}}}{\gamma}\right)$

Step 5: Calculate total - relation fuzzy matrix: After having established normalized direct-relation fuzzy matrix, a total-relation fuzzy matrix is calculated by making sure that $\lim \omega \rightarrow \infty F \omega=0$ (Equality-7). After, the crisp case of the total-relation fuzzy matrix (Equality (8)) is identified as follows. For each of the triangular fuzzy numbers $(1, \mathrm{~m}, \mathrm{u})$ (Equality- 8 ) which is shown below, it is carried out by dealing with them as a separate matrix and combined into a single total relation matrix represented by $\tilde{\mathrm{T}}$ (Equality (10)- Equality (11)- Equality (12)).

$$
\begin{aligned}
& \widetilde{T}=\lim _{\omega \rightarrow \infty}\left(\widetilde{F}+\widetilde{F}^{2}+\cdots+\widetilde{F}^{\omega}\right)=\widetilde{F}(I-\widetilde{F})^{-1} \\
& \widetilde{T}=\left[\begin{array}{ccc}
\widetilde{t}_{11} & \cdots & \widetilde{t}_{1 \mathrm{n}} \\
\vdots & \ddots & \vdots \\
\widetilde{t}_{\mathrm{n} 1} & \cdots & \widetilde{t}_{\mathrm{nn}}
\end{array}\right] \\
& \widetilde{t}_{\mathrm{ij}}=\left(\mathrm{l}_{\mathrm{ij}}, \mathrm{m}_{\mathrm{ij}}, \mathrm{u}_{\mathrm{ij}}\right)
\end{aligned}
$$

$$
\operatorname{Matrix}\left[\mathrm{l}_{\mathrm{ij}}\right]=\mathrm{F}_{\mathrm{l}} \chi\left(\mathrm{I}-\mathrm{F}_{\mathrm{l}}\right)^{-1}
$$

Step 6: Analyze the structural model: After having calculated matrix $\widetilde{T}$ (Equality 13), $\widetilde{R}_{i}+\widetilde{C}_{j}$ and $\widetilde{R}_{i}-\widetilde{C}_{j}$ are determined. In the Equality (14) and Equality (15), $\widetilde{R}_{i}$ and $\widetilde{C}_{j}$ denote the sum of the rows and columns of the matrix $\widetilde{T}$. While $\widetilde{R}_{i}+\widetilde{C}_{j}$ shows the importance of factor i, $\widetilde{R}_{i}-\widetilde{C}_{j}$ denotes the net effect of factor i.

$$
\begin{aligned}
& T=\left[t_{i j}\right]_{n x n} i, j=1,2, \ldots, n \\
& R_{i}=\sum_{1 \leq j \leq n}^{n} t_{i j} \\
& C_{j}=\sum_{1 \leq i \leq n}^{n} t_{i j}
\end{aligned}
$$

Step 7: Defuzzification of $\widetilde{R}_{i}+\widetilde{C}_{j}$ and $\widetilde{R}_{i}-\widetilde{C}_{j}:$ In this step, $\widetilde{R}_{i}+\widetilde{C}_{j}$ and $\widetilde{R}_{i}-\widetilde{C}_{j}$ are defuzzified by using Equation (16) and Equation (17). The abbreviation of "def" is the abbreviated form of the word "defuzzifying" which means defuzzification and defines the defuzzified values.

$$
\begin{aligned}
& \widetilde{R}_{i}^{\text {def }}+\widetilde{C}_{j}^{\text {def }}=\frac{1}{4}(l+2 m+h) \\
& \widetilde{R}_{i}^{\text {def }}-\widetilde{C}_{j}^{\text {def }}=\frac{1}{4}(l+2 m+h)
\end{aligned}
$$

Step 8: Building up the cause-effect relation diagram: in the last step, the cause and effect relation diagram is depicted by mapping the dataset of $\widetilde{R}_{i}+\widetilde{C}_{j}$ and $\widetilde{R}_{i}-\widetilde{C}_{j}$.

Step 9:Determination of factor weights. These weights are calculated by Equality (20).

$$
w_{i}=\sqrt{\left(\widetilde{R}_{i}^{d e f}+\widetilde{C}_{j}^{d e f}\right)^{2}+\left(\widetilde{R}_{i}^{d e f}-\widetilde{C}_{j}^{d e f}\right)^{2}}
$$

Then, the importance of any factor can be normalized shown as Equality (21):

$$
W_{i}=\frac{w_{i}}{\sum_{i}^{n} w_{i}}
$$




\section{RESEARCH DESIGN}

The application of the solution methodology is divided into two sub-sections: (1) questionnaire preparation and (2) data collection.

\subsection{Questionnaire Preparation}

In this study, thirteen evaluation criteria (barriers) are used as follows: (B1) lack of government support, (B2) lack of guidelines to adopt social dimensions in SSCM practices for industries, (B3) lack of community pressure, (B4) low market demand for sustainable products, (B5) there are few business-friendly policies, (B6) low price demand of the community, (B7) lack of infrastructure, (B8) lack of culture without engagement and support, (B9) corruption and mock compliance, (B10) disruptions in the operation of the work health and safety management system, (B11) the interests and rights of the employee are ignored, (B12) stakeholders'negative influence, (B13) ignoring the rights of the Stakeholders. The fuzzy DEMATEL method is also used to evaluate the impact of each barrier in the social dimension of the SSCM. Generally, the DEMATEL approach is to deal with the relationships of decision factors which are assessed by crisp values to establish a structural model. However, in many real-time situations, experts' opinions may be unclear, and exact numerical values can be inadequate to determine the vague interdependency relationships between the barriers. In this view, the concept of the fuzzy set is one of the suitable methodologies to get clear experts' opinion and many researchers agreed on
DEMATEL for improvement. Here, pairwise comparisons were made to evaluate the effect of each barrier. These effects are respectively "no effect (0)", "low effect (1)", "normal effect (2)", "high effect (3)" and "very high effect (4)"as defined.

\subsection{Data Collection}

Expert opinions were used in this study. Ten expert opinions (five academic staff and five sector experts) were taken into consideration. Evaluations were performed with consensus. The characteristics of the experts are given in Table 2 below.

The factors identified as thirteen barriers are mentioned above. Once the barriers (factors) of the social dimension of the SSCM have been defined, it is necessary to make pairwise comparisons between the barriers by decision-makers to create a fuzzy direct relationship matrix.

Pairwise comparisons between barriers are important for determining the sender(s) and receptor (affected) groups. However, it is not possible to determine exactly how effective a factor is on another factor when making comparisons. For this reason, it is considered appropriate to make comparisons with linguistic expressions using the fuzzy scale. For this purpose, a five-scale scale was created with no effect, low effect, moderate effect, high effect, and a very high degree of linguistic (Wu and Lee, 2007). This scale is given in Table 3.

Table 2: The characteristics of the experts

\begin{tabular}{|l|l|l|}
\hline Academic Staff & Area of Expertise & Years of Experience \\
\hline Expert 1 & SSCM & 10 Years \\
\hline Expert 2 & Environmental Sustainability & 15 Years \\
\hline Expert 3 & Sustainable Development & 17 Years \\
\hline Expert 4 & Supply Chain Management+MCDM & 20 Years \\
\hline Expert 5 & Supply Chain Management+MCDM & 9 Years \\
\hline Sector Expert & Area of Expertise & Years of Experience \\
\hline Expert 6 & Environmental Engineering & 8 Years \\
\hline Expert 7 & Environmental Engineering & 10 Years \\
\hline Expert 8 & Supply Chain Management & 25 Years \\
\hline Expert 9 & Sustainability & 5 Years \\
\hline Expert 10 & Sustainability & 7 Years \\
\hline
\end{tabular}

Table 3: The Fuzzy Linguistic Scale (Wu and Lee, 2007)

\begin{tabular}{|l|l|l|}
\hline Linguistic terms & Influence score & Triangular fuzzy numbers \\
\hline No influence $(\mathrm{No})$ & 0 & $(0,0,0.25)$ \\
\hline Very low influence $(\mathrm{VL})$ & 1 & $(0,0.25,0.50)$ \\
\hline Low influence $(\mathrm{L})$ & 2 & $(0.25,0.50,0.75)$ \\
\hline High influence $(\mathrm{H})$ & 3 & $(0.50,0.75,1.00)$ \\
\hline Very high influence $(\mathrm{VH})$ & 4 & $(0.75,1.00,1.00)$ \\
\hline
\end{tabular}


To establish a fuzzy direct relationship matrix, experts were asked to make pairwise comparisons between the factors to determine which factor influenced another factor by using the effect values corresponding to the linguistic expressions given in Table 3. The matrices created according to the effect value of linguistic expressions are rearranged according to the triangular fuzzy numbers $\left(\mathrm{l}_{\mathrm{ij}}, \mathrm{m}_{\mathrm{ij}} \mathrm{u}_{\mathrm{ij}}\right)$. Using Equation (1), a fuzzy direct relation matrix was obtained. Table 4 shows the Fuzzy Direct Relationship Matrix.

For the normalization process to be performed by using the Equations (5) and (6), the triangular fuzzy number values of all rows and columns in the fuzzy direct relationship matrix formed in the previous stage were collected separately, the highest values for the first, second, and third have been identified. All triangular numbers in the fuzzy direct relationship matrix were divided by the highest number value belonging to their block and the normalized fuzzy direct relationship matrix was obtained. Table 5 shows the Normalized Fuzzy Direct Relationship Matrix.

Three new matrices were obtained by combining the values of $\mathrm{I}, \mathrm{m}$, and $\mathrm{u}$ of each triangular fuzzy number in the normalized fuzzy direct relationship matrix. The
Normalized Fuzzy Direct Relationship Matrix was revised according to these matrices. Each of these matrices was subtracted from the matrix of the matrix and multiplied by the matrices formed according to the values of $1, m$ and, $u$ by the inversion of the new matrices obtained. These matrices were then combined to form a fuzzy total relationship matrix.

After the formation of a fuzzy total relationship matrix, $\widetilde{R}_{i}$ and $\widetilde{C}_{i}$ values were determined. The row values of the $R$ fuzzy total relationship matrix, which shows the sum of the direct or indirect effects sent by other factors to a factor, were obtained by adding the column values to the same factor, which represents the sum of the effects from the other factors. After calculating these values, $\left(\widetilde{R}_{i}+\widetilde{C}_{i}\right)$ and $\left(\widetilde{R}_{i}-\widetilde{C}_{i}\right)$ were calculated for each factor. The values obtained as a result of the calculations are shown in Table 6.

Factors with high $\left(\widetilde{R}_{i}+\widetilde{C}_{i}\right)$ are more strongly associated with other factors. Factors with a positive $\left(\widetilde{R}_{i}+\widetilde{C}_{i}\right)$ value have more effect on other factors. These factors, which are expressed as influencers, are considered to have more priority. Factors with a negative $\left(\widetilde{R}_{i}+\widetilde{C}_{i}\right)$ value have a lower priority. These factors, expressed as affected, are more affected by other factors. 


\begin{tabular}{|c|c|c|c|c|c|c|c|c|c|c|c|c|c|}
\hline$\frac{m}{\infty}$ & 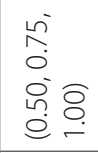 & $\begin{array}{l}\text { ñ } \\
0 \\
0 \\
0 \\
\stackrel{0}{0} \\
e \\
0\end{array}$ & $\begin{array}{l}\text { ñ } \\
0 \\
0 \\
0 \\
0 \\
0 \\
0\end{array}$ & $\begin{array}{l}\text { 峁 } \\
0 \\
0 \\
0\end{array}$ & 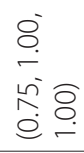 & 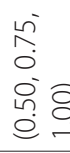 & $\begin{array}{l}\text { No } \\
0 \\
0 \\
0 \\
0 \\
0 \\
0\end{array}$ & $\begin{array}{l}8 \\
\dot{0} \\
\text { ñ. } \\
\text { é }\end{array}$ & $\begin{array}{l}8 \\
\dot{0} \\
\text { ñ. } \\
\text { é }\end{array}$ & 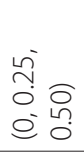 & $\begin{array}{l}8 \\
\dot{0} \\
\text { No } \\
\stackrel{0}{0}\end{array}$ & $\begin{array}{l}\widehat{\Omega} \\
0 \\
0 \\
0 \\
0\end{array}$ & $\begin{array}{l}\widetilde{\widetilde{N}} \\
0\end{array}$ \\
\hline
\end{tabular}

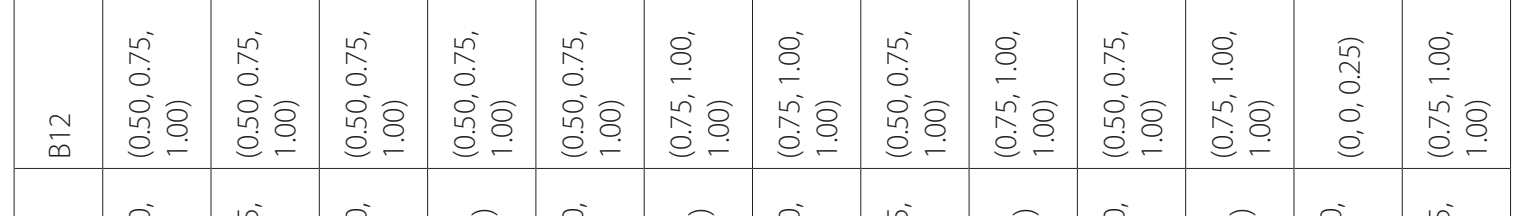

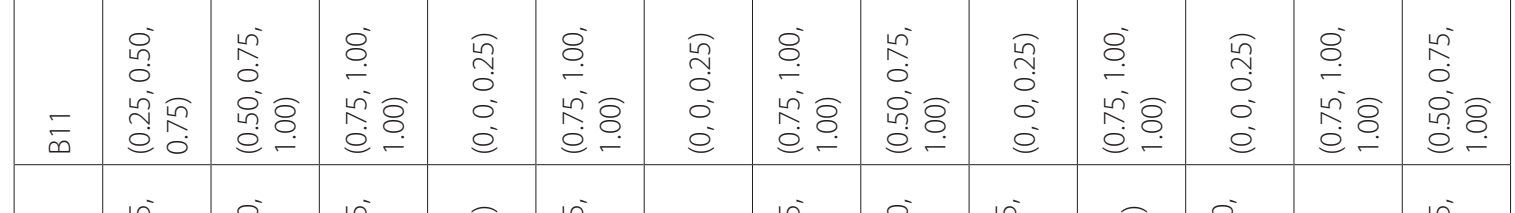

\begin{tabular}{|c|c|c|c|c|c|c|c|c|c|c|c|c|c|}
\hline$\stackrel{\circ}{\infty}$ & 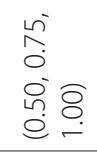 & 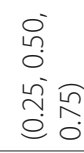 & 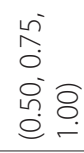 & 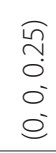 & 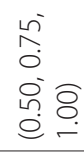 & $\begin{array}{l}\text { 崩 } \\
0 \\
0 \\
0 \\
0\end{array}$ & 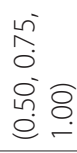 & 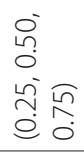 & 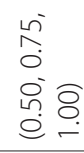 & 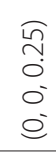 & 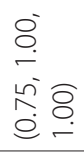 & $\begin{array}{l}\text { 崩 } \\
0 \\
0 \\
0 \\
0\end{array}$ & 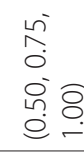 \\
\hline
\end{tabular}

\begin{tabular}{|c|c|c|c|c|c|c|c|c|c|c|c|c|c|}
\hline ळ & 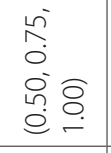 & $\begin{array}{l}\text { ñ } \\
0 \\
0 \\
0 \\
\stackrel{n}{0} \\
e \\
0\end{array}$ & $\begin{array}{l}\text { ñ } \\
0 \\
0 \\
0 \\
\stackrel{0}{0} \\
e\end{array}$ & $\begin{array}{l}\widehat{\Omega} \\
\stackrel{0}{0} \\
0 \\
0 \\
0\end{array}$ & 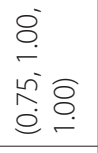 & 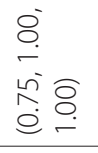 & 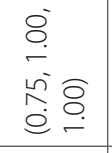 & 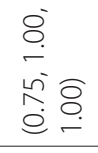 & $\begin{array}{l}\widehat{\Omega} \\
0 \\
0 \\
0 \\
0 \\
0\end{array}$ & 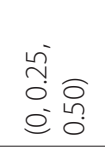 & 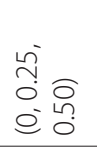 & 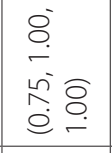 & 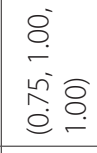 \\
\hline & & & & & & & & & & & & & \\
\hline
\end{tabular}

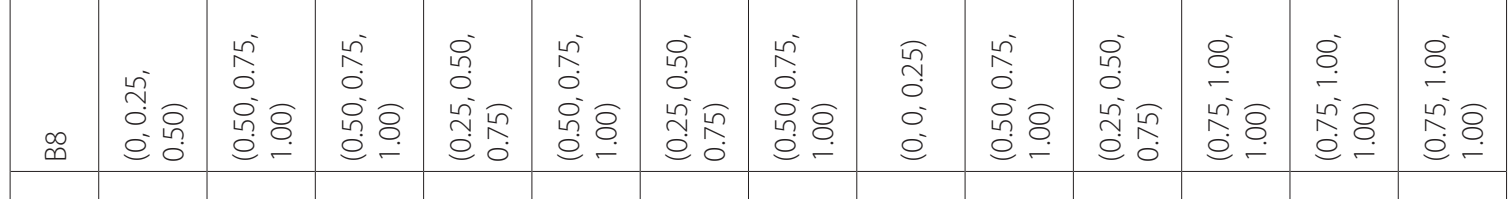

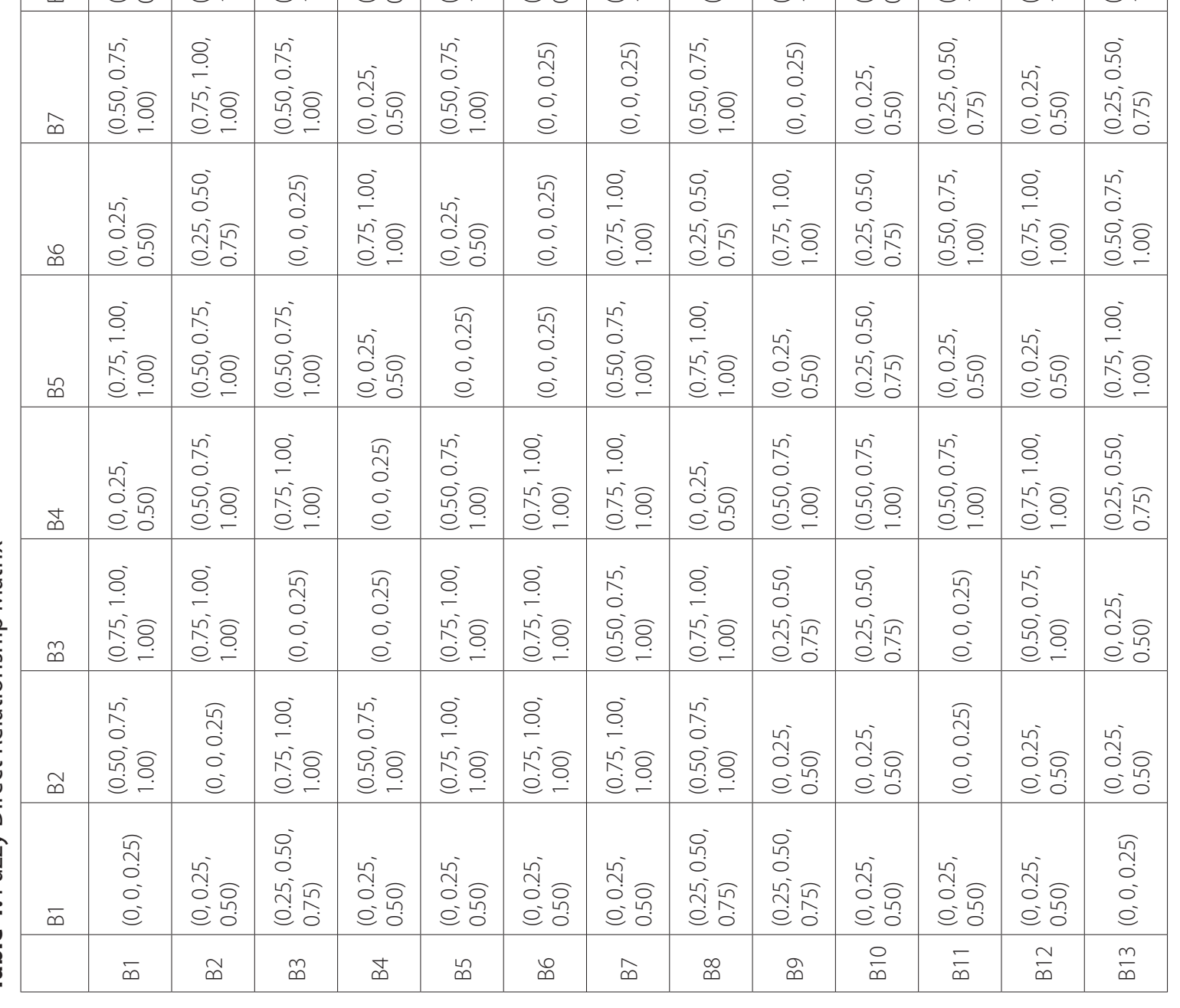




\begin{tabular}{|c|c|c|c|c|c|c|c|c|c|c|c|c|c|}
\hline$\frac{m}{\infty}$ & 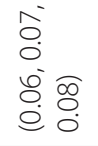 & $\begin{array}{l}\hat{0} \\
0 \\
\stackrel{0}{0} \\
\stackrel{0}{0} \\
\dot{e}\end{array}$ & 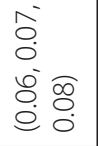 & 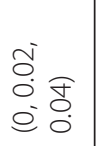 & $\begin{array}{l}0 \\
0 \\
0 \\
\circ \\
\circ \\
\dot{0} \\
0 \\
0\end{array}$ & 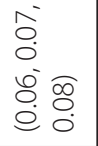 & $\begin{array}{l}\hat{0} \\
0 \\
\delta^{\circ} \\
\stackrel{0}{0} \\
\dot{0}\end{array}$ & 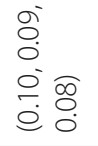 & 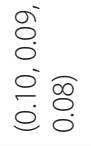 & $\begin{array}{l}\tilde{c} \\
0 \\
0 \\
0 \\
0 \\
0\end{array}$ & $\begin{array}{l}0 \\
0 \\
0 \\
\circ \\
\circ \\
\stackrel{0}{0} \\
0 \\
0\end{array}$ & $\begin{array}{l}0 \\
0 \\
0 \\
\circ \\
\circ \\
0 \\
0 \\
0\end{array}$ & $\begin{array}{l}\overparen{\Xi} \\
0 \\
0 \\
0 \\
0 \\
0\end{array}$ \\
\hline$\frac{\sim}{\infty}$ & $\begin{array}{l}\hat{0} \\
0 \\
\circ \\
\delta \\
\varnothing \\
0\end{array}$ & 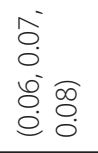 & $\begin{array}{l}\hat{0} \\
0 \\
0 \\
\delta^{-} \\
0 \\
0 \\
0\end{array}$ & 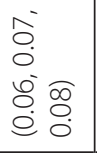 & 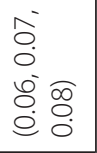 & $\begin{array}{l}0 \\
0 \\
0 \\
0 \\
0 \\
0 \\
0 \\
0\end{array}$ & 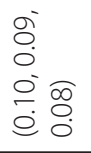 & 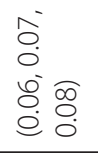 & 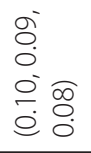 & 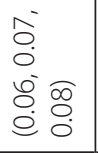 & 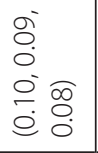 & $\begin{array}{l}\widehat{\Xi} \\
0 \\
0 \\
0 \\
0 \\
0\end{array}$ & 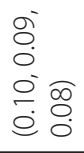 \\
\hline $\bar{\infty}$ & $\begin{array}{l}\dot{0} \\
0 \\
\text { mi } \\
0 \\
0 \\
\dot{0}\end{array}$ & 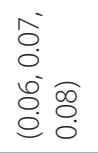 & $\begin{array}{l}0 \\
0 \\
0 \\
0 \\
0 \\
\stackrel{0}{0} \\
0 \\
0\end{array}$ & $\begin{array}{l}\text { ฮ̦ } \\
0 \\
0 \\
0 \\
0\end{array}$ & $\begin{array}{l}0 \\
0 \\
0 \\
0 \\
\circ \\
\stackrel{0}{0} \\
0 \\
0\end{array}$ & 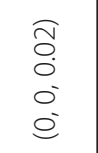 & 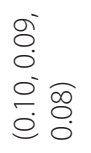 & 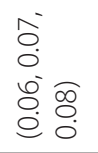 & $\begin{array}{l}\widehat{\Xi} \\
0 \\
0 \\
0 \\
0 \\
0\end{array}$ & 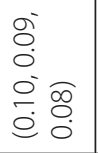 & $\begin{array}{l}\text { ฮ̦ } \\
0 \\
0 \\
0 \\
0 \\
0\end{array}$ & $\begin{array}{l}0 \\
0 \\
0 \\
0 \\
\circ \\
\stackrel{0}{0} \\
0 \\
0\end{array}$ & $\begin{array}{l}\hat{0} \\
0 \\
\dot{0} \\
\stackrel{0}{0} \\
\stackrel{0}{0} \\
\dot{0}\end{array}$ \\
\hline$\frac{\circ}{\infty}$ & 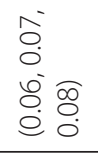 & $\begin{array}{l}\dot{0} \\
0 \\
\text { ñ. } \\
0 \\
\dot{e} \\
\dot{0}\end{array}$ & 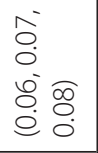 & $\begin{array}{l}\text { đิ } \\
0 \\
0 \\
0 \\
0 \\
0\end{array}$ & 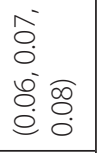 & 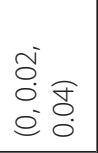 & 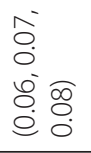 & $\begin{array}{l}\dot{0} \\
0.0 \\
\text { ñ. } \\
0 \\
\dot{e} \\
\end{array}$ & 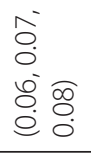 & $\begin{array}{l}\widehat{\Xi} \\
0 \\
0 \\
0 \\
0 \\
0\end{array}$ & $\begin{array}{l}0 \\
0 \\
0 \\
0 \\
\circ \\
\stackrel{0}{0} \\
0 \\
0\end{array}$ & $\begin{array}{l}\tilde{y} \\
0 \\
0 \\
0 \\
0\end{array}$ & 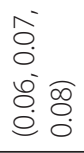 \\
\hline ळे & 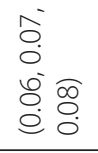 & 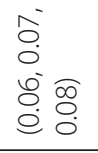 & 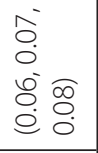 & $\begin{array}{l}\text { త్ } \\
0 \\
0 \\
0 \\
0 \\
0\end{array}$ & $\begin{array}{l}0 \\
0 \\
0 \\
0 \\
0 \\
0 \\
0 \\
0\end{array}$ & 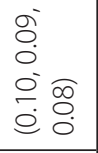 & $\begin{array}{l}0 \\
0 \\
0 \\
\circ \\
\circ \\
0 \\
0\end{array}$ & 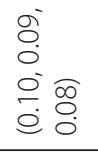 & $\begin{array}{l}\overparen{\Xi} \\
0 \\
0 \\
0 \\
0 \\
0 \\
0\end{array}$ & 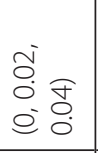 & 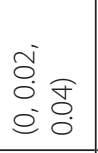 & $\begin{array}{l}o \\
0 \\
0 \\
0 \\
0 \\
\dot{0} \\
0 \\
0\end{array}$ & 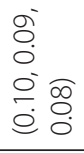 \\
\hline$\stackrel{\infty}{\infty}$ & $\begin{array}{l}\tilde{J} \\
0 \\
0 \\
0 \\
0 \\
0\end{array}$ & 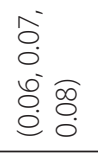 & 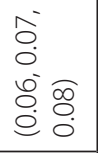 & $\begin{array}{l}\dot{0} \\
\dot{0} \\
\text { n் } \\
0 \\
\dot{\theta} \\
\dot{0}\end{array}$ & 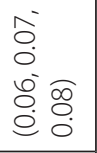 & 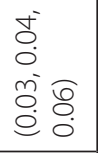 & 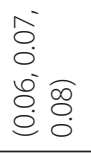 & $\begin{array}{l}\widehat{\sigma} \\
0 \\
0 \\
0 \\
0 \\
0\end{array}$ & $\begin{array}{l}\hat{0} \\
0 \\
\stackrel{0}{0} \\
\stackrel{0}{0} \\
\dot{e} \\
\dot{0}\end{array}$ & $\begin{array}{l}\dot{\delta} \\
\dot{0} \\
\tilde{n} \\
0 \\
\dot{\theta} \\
\dot{0} \\
0\end{array}$ & $\begin{array}{l}0 \\
0 \\
0 \\
0 \\
\circ \\
\stackrel{0}{0} \\
0 \\
0\end{array}$ & 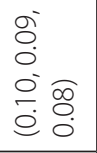 & 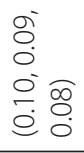 \\
\hline$\widehat{\infty}$ & 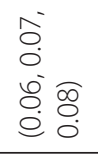 & 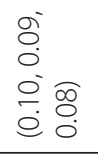 & 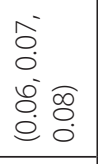 & 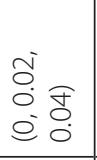 & 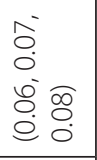 & $\begin{array}{l}\widehat{\Xi} \\
0 \\
0 \\
0 \\
0 \\
0\end{array}$ & $\begin{array}{l}\overparen{\Xi} \\
0 \\
0 \\
0 \\
0 \\
e^{-}\end{array}$ & 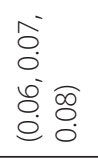 & $\begin{array}{l}\widehat{\sigma} \\
0 \\
0 \\
0 \\
0 \\
0\end{array}$ & 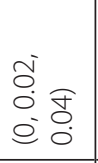 & 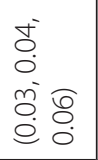 & 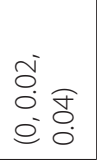 & 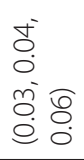 \\
\hline$\stackrel{\infty}{\infty}$ & $\begin{array}{l}\tilde{D} \\
0 \\
0 \\
0 \\
0 \\
0\end{array}$ & $\begin{array}{l}\text { ठ } \\
0 \\
0 \\
\text { m. } \\
0 \\
0 \\
0\end{array}$ & $\begin{array}{l}\widehat{\sigma} \\
0 \\
0 \\
0 \\
0 \\
0 \\
0\end{array}$ & 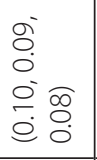 & 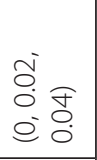 & 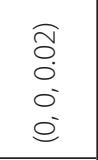 & $\begin{array}{l}\sigma^{\circ} \\
0 \\
0 \\
0^{\circ} \\
\stackrel{0}{0} \\
\stackrel{0}{0}\end{array}$ & $\begin{array}{l}\dot{0} \\
0 \\
0 \\
\text { m. } \\
0 \\
0\end{array}$ & 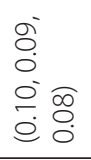 & 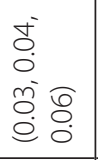 & 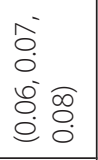 & $\begin{array}{l}0 \\
0 \\
0 \\
0 \\
\circ \\
\stackrel{0}{0} \\
0\end{array}$ & 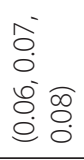 \\
\hline$\stackrel{\llcorner}{\infty}$ & $\begin{array}{l}\sigma^{\circ} \\
0 \\
\circ \\
\circ \\
0 \\
0 \\
0\end{array}$ & 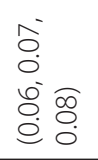 & 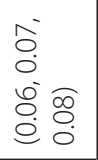 & $\begin{array}{l}\tilde{c} \\
\dot{0} \\
\dot{0} \\
\dot{0} \\
0 \\
0\end{array}$ & $\begin{array}{l}\widehat{\Xi} \\
0 \\
0 \\
0 \\
0^{\circ}\end{array}$ & 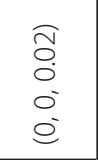 & 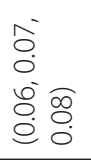 & $\begin{array}{l}\circ \\
0 \\
0 \\
\circ \\
\circ \\
\stackrel{0}{0} \\
\stackrel{0}{0}\end{array}$ & $\begin{array}{l}\widehat{\Xi} \\
0 \\
0 \\
0 \\
0^{\circ}\end{array}$ & $\begin{array}{l}\dot{0} \\
\dot{0} \\
\text { mi } \\
\stackrel{0}{\delta} \\
\dot{e} \\
0\end{array}$ & $\begin{array}{l}\widetilde{\Xi} \\
0 \\
0 \\
0 \\
0^{\circ}\end{array}$ & $\begin{array}{l}\widehat{\Xi} \\
\text { Oे } \\
0 \\
0 \\
\text { ¿ }\end{array}$ & $\begin{array}{l}\circ \\
\circ \\
0 \\
\circ \\
\circ \\
\dot{0} \\
\end{array}$ \\
\hline 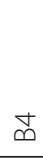 & $\begin{array}{l}\overparen{\partial} \\
0 \\
0 \\
0 \\
0 \\
0\end{array}$ & 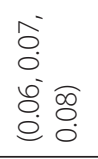 & $\begin{array}{l}0 \\
0 \\
0 \\
0 \\
0 \\
0 \\
0 \\
0\end{array}$ & $\begin{array}{l}\text { త } \\
0 \\
0 \\
0 \\
0 \\
0\end{array}$ & 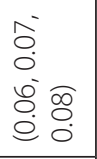 & 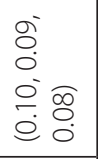 & $\begin{array}{l}\circ \\
0 \\
0 \\
0 \\
\circ \\
\stackrel{0}{0} \\
\stackrel{0}{0}\end{array}$ & $\begin{array}{l}\widehat{\Xi} \\
0 \\
0 \\
0 \\
0 \\
0\end{array}$ & 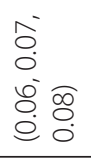 & 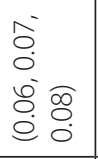 & 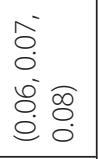 & $\begin{array}{l}0 \\
0 \\
0 \\
0 \\
\circ \\
0 \\
0 \\
0\end{array}$ & $\begin{array}{l}\text { ठ் } \\
0 \\
\text { m. } \\
0 \\
0 \\
0\end{array}$ \\
\hline$\stackrel{m}{\infty}$ & $\begin{array}{l}\rho_{0} \\
0 \\
\circ \\
\circ \\
0 \\
0 \\
0\end{array}$ & $\begin{array}{l}\circ \\
0 \\
0 \\
\circ \\
\circ \\
\stackrel{0}{0} \\
0\end{array}$ & $\begin{array}{l}\widehat{\Xi} \\
0 \\
0 \\
0 \\
0 \\
0\end{array}$ & $\begin{array}{l}\text { తิ } \\
0 \\
0 \\
0 \\
0 \\
0\end{array}$ & $\begin{array}{l}0 \\
0 \\
0 \\
\circ \\
\circ \\
\stackrel{0}{0} \\
\dot{0} \\
0\end{array}$ & $\begin{array}{l}0 \\
0 \\
0 \\
0 \\
\circ \\
\stackrel{0}{0} \\
\dot{0} \\
0\end{array}$ & 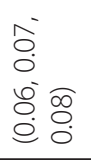 & $\begin{array}{l}\circ \\
0 \\
0 \\
\circ \\
\circ \\
\stackrel{0}{0} \\
0\end{array}$ & $\begin{array}{l}\widehat{\jmath} \\
0 \\
0 \\
0 \\
0 \\
0^{\prime}\end{array}$ & $\begin{array}{l}\widehat{\Xi} \\
0 \\
0 \\
0 \\
0 \\
0^{\circ}\end{array}$ & $\begin{array}{l}\widehat{I} \\
0 \\
0 \\
0 \\
0^{\circ} \\
0^{-}\end{array}$ & 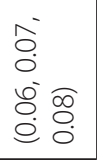 & $\begin{array}{l}\widehat{\Xi} \\
0 \\
0 \\
0 \\
0 \\
0^{\circ}\end{array}$ \\
\hline$\widetilde{\infty}$ & 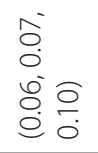 & $\begin{array}{l}\widehat{\sigma} \\
0 \\
0 \\
0 \\
0 \\
0\end{array}$ & 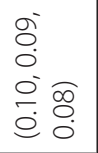 & $\begin{array}{l}\hat{0} \\
\dot{0} \\
\delta_{0}^{-} \\
\dot{0} \\
\dot{0} \\
0\end{array}$ & $\begin{array}{l}0 \\
0 \\
0 \\
\circ \\
\circ \\
0 \\
0 \\
0\end{array}$ & $\begin{array}{l}0 \\
0 \\
0 \\
0 \\
\circ \\
0 \\
\\
0\end{array}$ & $\begin{array}{l}\sigma \\
0 \\
0 \\
0 \\
\circ \\
\stackrel{0}{0} \\
\stackrel{0}{0} \\
0\end{array}$ & 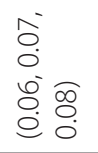 & $\begin{array}{l}\tilde{D} \\
0 \\
0 \\
0 \\
0\end{array}$ & $\begin{array}{l}\tilde{c} \\
0 \\
0 \\
0 \\
0 \\
0 \\
0\end{array}$ & $\begin{array}{l}\text { త్ } \\
0 \\
0 \\
0 \\
0 \\
0\end{array}$ & 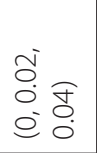 & 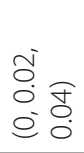 \\
\hline $\bar{\infty}$ & $\begin{array}{l}\widehat{\sigma} \\
0 \\
0 \\
0 \\
0 \\
0 \\
\end{array}$ & $\begin{array}{l}\tilde{O} \\
0 \\
0 \\
e^{-} \\
\end{array}$ & $\begin{array}{l}\dot{0} \\
0 \\
0 \\
\tilde{n} \\
0 \\
\dot{e} \\
0\end{array}$ & $\begin{array}{l}\tilde{c} \\
\dot{0} \\
\dot{0} \\
\dot{0} \\
\dot{0} \\
0\end{array}$ & $\begin{array}{l}\tilde{J} \\
\dot{0} \\
\dot{0} \\
\dot{0} \\
\\
0\end{array}$ & 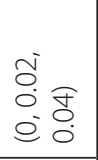 & $\begin{array}{l}\tilde{J}^{\top} \\
0^{\circ} \\
e^{\circ} \\
\end{array}$ & $\begin{array}{l}\dot{0} \\
0 \\
0 \\
\text { m. } \\
0 \\
0\end{array}$ & 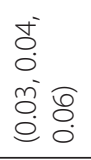 & 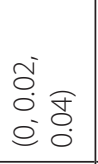 & $\begin{array}{l}\tilde{y} \\
0 \\
0 \\
0 \\
0 \\
0 \\
0\end{array}$ & $\begin{array}{l}\tilde{y} \\
0 \\
0 \\
0 \\
0 \\
0\end{array}$ & $\begin{array}{l}\widetilde{\Xi} \\
0 \\
0 \\
0 \\
0 \\
0^{-}\end{array}$ \\
\hline & $\bar{\infty}$ & $\widetilde{\infty}$ & $m$ & ¿े & $\stackrel{\iota}{\infty}$ & $\infty$ & $\widehat{\infty}$ & $\infty$ & $\infty$ & $\frac{\circ}{\infty}$ & $\overline{\bar{\infty}}$ & $\bar{\infty}$ & $\frac{m}{\infty}$ \\
\hline
\end{tabular}


Table 6: Cause and Effect Factor Groups

\begin{tabular}{|c|c|c|c|c|c|c|c|c|c|c|c|c|}
\hline \multirow[b]{2}{*}{ Barriers } & \multicolumn{3}{|c|}{$\mathbf{R}$} & \multicolumn{3}{|c|}{$C$} & \multicolumn{3}{|c|}{$\mathrm{R}+\mathrm{C}$} & \multicolumn{3}{|c|}{$\mathrm{R}-\mathrm{C}$} \\
\hline & 1 & $\mathrm{~m}$ & u & 1 & $\mathrm{~m}$ & U & I & $\mathrm{m}$ & u & 1 & $m$ & u \\
\hline B1 & 1,97 & 2,79 & 4,31 & 0,32 & 1,27 & 2,77 & 2,30 & 4,06 & 7,09 & 1,65 & 1,53 & 1,54 \\
\hline B2 & 2,23 & 3,01 & 4,56 & 1,63 & 2,44 & 3,81 & 3,86 & 5,45 & 8,37 & 0,61 & 0,57 & 0,74 \\
\hline B3 & 2,32 & 3,04 & 4,57 & 1,74 & 2,45 & 3,73 & 4,06 & 5,48 & 8,30 & 0,59 & 0,59 & 0,84 \\
\hline B4 & 0,82 & 1,47 & 2,90 & 2,32 & 3,08 & 4,47 & 3,14 & 4,55 & 7,37 & $-1,50$ & $-1,60$ & $-1,57$ \\
\hline B5 & 2,45 & 3,21 & 4,56 & 1,45 & 2,01 & 3,41 & 3,90 & 5,23 & 7,96 & 1,00 & 1,20 & 1,15 \\
\hline B6 & 1,74 & 2,32 & 3,54 & 2,06 & 2,76 & 4,05 & 3,80 & 5,08 & 7,60 & $-0,32$ & $-0,44$ & $-0,51$ \\
\hline B7 & 2,67 & 3,40 & 4,73 & 1,18 & 1,95 & 3,51 & 3,84 & 5,35 & 8,24 & 1,49 & 1,45 & 1,22 \\
\hline B8 & 2,38 & 3,13 & 4,51 & 2,31 & 3,05 & 4,49 & 4,69 & 6,18 & 9,00 & 0,07 & 0,08 & 0,02 \\
\hline B9 & 1,48 & 2,11 & 3,49 & 2,36 & 3,04 & 4,24 & 3,84 & 5,15 & 7,73 & $-0,88$ & $-0,93$ & $-0,74$ \\
\hline B10 & 0,92 & 1,89 & 3,42 & 1,60 & 2,38 & 4,00 & 2,52 & 4,27 & 7,41 & $-0,68$ & $-0,50$ & $-0,58$ \\
\hline B11 & 1,59 & 2,20 & 3,48 & 2,12 & 2,66 & 3,95 & 3,72 & 4,86 & 7,44 & $-0,53$ & $-0,46$ & $-0,47$ \\
\hline $\mathrm{B} 12$ & 1,88 & 2,61 & 3,81 & 2,84 & 3,55 & 4,93 & 4,72 & 6,16 & 8,74 & $-0,96$ & $-0,94$ & $-1,13$ \\
\hline B13 & 1,95 & 2,69 & 4,01 & 2,49 & 3,23 & 4,53 & 4,44 & 5,92 & 8,55 & $-0,54$ & $-0,54$ & $-0,52$ \\
\hline
\end{tabular}

The values of $\left(\widetilde{R}_{i}+\widetilde{C}_{i}\right)$ and $\left(\widetilde{R}_{i}-\widetilde{C}_{i}\right)$ calculated in the previous step were calculated as triangular fuzzy numbers $(1, m, h)$. To convert these numbers into a crisp number, the number of Equations (14) and (15) were used for the decimation. As a result of this process, the new values obtained for each factor $\left(\widetilde{R}_{i}+\widetilde{C}_{i}\right)$ and $\left(\widetilde{R}_{i}-\widetilde{C}_{i}\right)$ are shown in Table 7.

Table 7: Defuzzification of Cause and Effect Factor Groups

\begin{tabular}{|l|l|l|}
\hline Barriers & $\mathbf{R}+\mathbf{C}$ & $\mathbf{R}-\mathbf{C}$ \\
\hline B1 & 4,374212 & 1,55864 \\
\hline B2 & 5,781228 & 0,619941 \\
\hline B3 & 5,829786 & 0,652258 \\
\hline B4 & 4,90543 & $-1,56836$ \\
\hline B5 & 5,579428 & 1,138353 \\
\hline B6 & 5,388538 & $-0,4299$ \\
\hline B7 & 5,696133 & 1,405068 \\
\hline B8 & 6,513772 & 0,060668 \\
\hline B9 & 5,468478 & $-0,86991$ \\
\hline B10 & 4,620217 & $-0,56281$ \\
\hline B11 & 5,220126 & $-0,47802$ \\
\hline B12 & 6,444318 & $-0,99393$ \\
\hline B13 & 6,204333 & $-0,532$ \\
\hline
\end{tabular}

Equations (16) and (17) were used to determine the factor weights. As a result of the calculations, the factor weights in Table 8 were determined.
Table 8: Factor Weights

\begin{tabular}{|l|l|l|}
\hline Barriers & $\mathbf{w}_{\mathbf{i}}$ & $\mathbf{w}_{\mathbf{i}}$ \\
\hline B1 & 4,64361 & 0,06349 \\
\hline B2 & 5,81437 & 0,0795 \\
\hline B3 & 5,86616 & 0,08021 \\
\hline B4 & 5,15005 & 0,07042 \\
\hline B5 & 5,69437 & 0,07786 \\
\hline B6 & 5,40566 & 0,07391 \\
\hline B7 & 5,86687 & 0,08022 \\
\hline B8 & 6,51405 & 0,08907 \\
\hline B9 & 5,53724 & 0,07571 \\
\hline B10 & 4,65437 & 0,06364 \\
\hline B11 & 5,24197 & 0,07167 \\
\hline B12 & 6,52052 & 0,08916 \\
\hline B13 & 6,2271 & 0,08514 \\
\hline
\end{tabular}

\section{RESULTS AND DISCUSSION}

Today, industries are under pressure to consider the environmental management concept in their traditional practice to achieve sustainable improvements. In this view, researchers and academicians were given priority to implement and ensure the social dimension of SSCM practices. However, it is difficult to implement the social dimension without eradicating the barriers. In this study, the barriers encountered in the realization of the social dimension of the SSCM have been defined. The Fuzzy DEMATEL method is used to determine the priority barriers across the social dimension in Turkey. 
Thirteen barriers were identified after the literature review. To prioritize these barriers, 10 expert opinions including 5 academic staff and 5 sector employee opinions were obtained.

The first barrier to be taken into consideration in the fuzzy DEMATEL is "stakeholders' negative influence (B12)". The second important barrier is "lack of culture without engagement and support(B8)". The barrier of "ignoring the rights of stakeholders (B13)" is third. The next major barrier is "lack of community pressure (B3)". The fifth barrier is "lack of guidelines to adopt social dimension in SSCM practices for industries (B2)". The sixth, seventh, and eighth barriers are "lack of infrastructure (B7)", "there are few business-friendly policies (B5)" and "corruption and mock compliance (B9)" respectively. "Low price request of the community (B6)" is the ninth barrier. In the tenth and eleventh barriers are "the interests and rights are ignored (B11)" and "low market demand for sustainable products (B4)" respectively. In the last two orders, there are the barriers, "disruptions of the health and safety management system (B10)" and "lack of government support (B1)" respectively.

The cause-effect relationship diagram obtained after the defuzzification process is given in Figure 2.

According to Fig. 2; B1, B7, B5, B3, B2, and B8 are determined as the factors that cause, other factors were found to be effective factors. Among these factors, it is explicit that "lack of government support (B1)" has the highest power to influence other factors.

This study identified the main barriers to be eliminated during the implementation of the social dimension of the SSCM. In this study, specific barriers were given priorities considering the opinions of experts by following the Fuzzy DEMATEL method. In industries, it is not possible to remove all barriers while starting the implementation of the social dimension of the SSCM. This paper provided comprehensive solutions for the identification of key barriers in industries. The study revealed that Turkish industries still lack the awareness of the social dimension of the SSCM.

\section{CONCLUSIONS \& RECOMMENDATIONS}

The development of the social dimension of SSCM in the industrial sector has become a popular trend. In addition to environmental and economic dimensions, companies are also trying to implement the social dimension. However, as in other dimensions, there are many barriers to the social dimension. Therefore, this study is conducted to identify the barriers encountered in the social dimension of SSCM in Turkey and to indicate the priorities. Analyzing the causes of the barriers mentioned cannot be a study on this social dimension in Turkey.

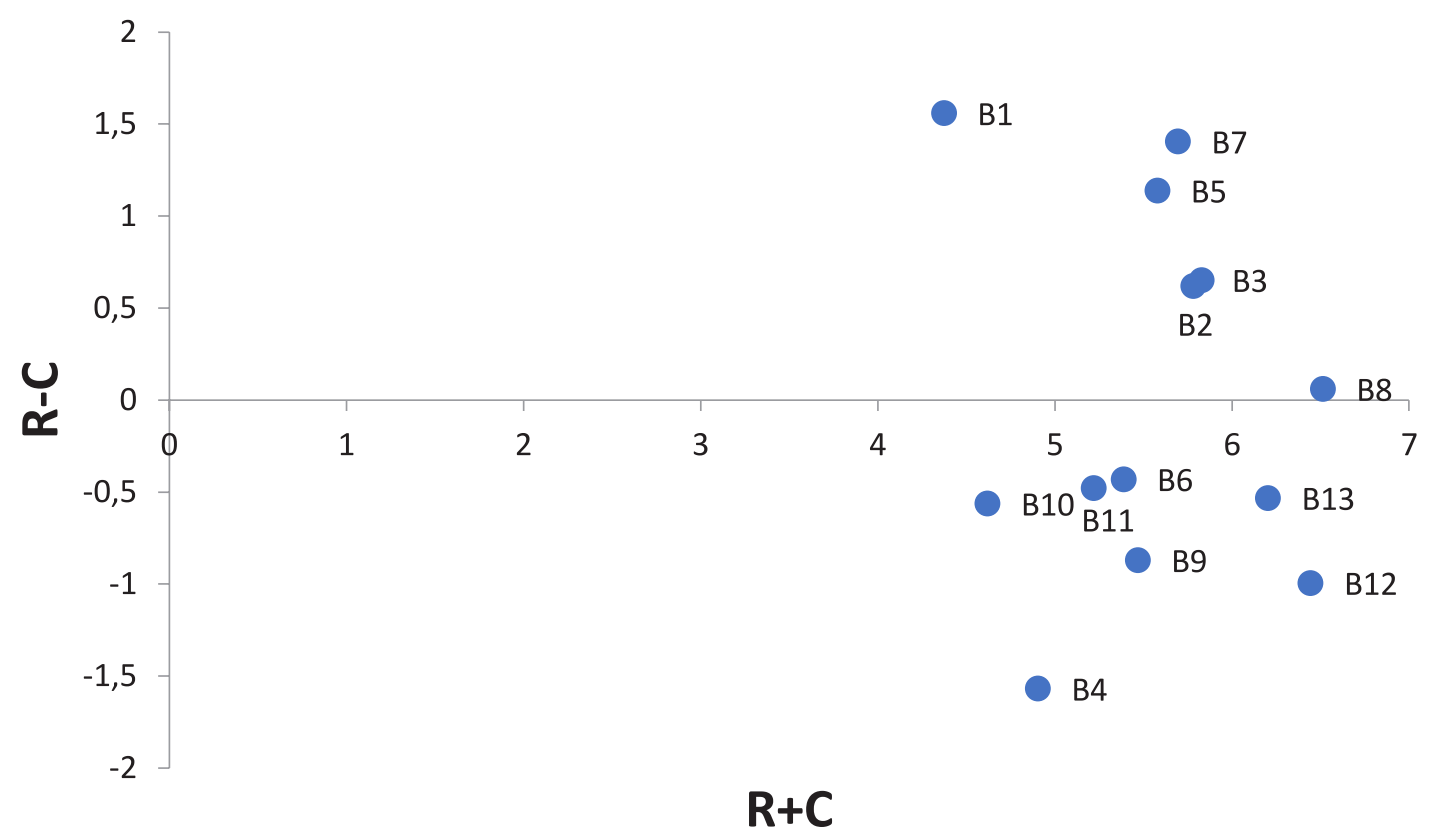

Figure 2: The cause-effect relationship diagram 
The findings revealed that 6 barriers belong to the causal group and 7 barriers belong to the effect group. "Lack of government support (B1)", "lack of infrastructure (B7),", there are few business-friendly policies (B5)", "lack of community pressure (B3)","lack of guidelines to adopt social dimension in SSCM practices for industries (B2)" and "lack of culture without engagement and support (B8)" seem to be the most important casual barriers. "Low market demand for sustainable products (B4)" and "stakeholders" negative influence (B12)" seems to be the most important influential barriers. This means that other barriers can easily affect these barriers and that improving other barriers can directly affect them. Also, the findings of this study have important implications for policy-makers and academicians:

The findings of this study can help companies in the proper implementation of the social dimension of the SSCM by developing strategies to overcome these barriers.

The findings of this study may help to better understand the impact of the social dimension of the SSCM on the company performance.

"Stakeholders' negative influence (B12)" is the biggest barrier to the social dimension. Therefore, for a developing country such as Turkey, stakeholders should be educated on this issue and should work together to improve their processes.

In this study, an idea for the adoption and implementation of the social dimension in Turkey was proposed.

\subsection{Limitations \& Scope of the research}

The aim of the study was successfully carried out within the scope of some limitations. The lack of a social dimension of sustainability in the literature is an undeniable fact. The factors used in the study were developed using empirical evidence.

This study is an important contribution to managers. The supply chain gives an idea of the social dimension practices that have a significant impact on sustainability. Also, it provides information to companies on the importance of economic and environmental sustainability, as well as the importance of social sustainability.

In future research, these barriers can be improved by using more resources and experts. It would be interesting to compare the same studies in different countries. This research can also be investigated using various methods such as AHP, ANP, and PROMETHEE. 


\section{REFERENCES}

Ahmadi, H. B., Kusi-Sarpong, S., \& Rezaei, J. (2017). Assessing the social sustainability of supply chains using Best Worst Method. Resources, Conservation and Recycling, 126, 99-106.

Al Zaabi, S., Al Dhaheri, N., \& Diabat, A. (2013). Analysis of interaction between the barriers for the implementation of sustainable supply chain management. The International Journal of Advanced Manufacturing Technology, 68(1-4), 895-905.

Al Khidir, T., \& Zailani, S. (2009). Going green in supply chain towards environmental sustainability. Global Journal of Environmental Research, 3(3), 246-251.

Amindoust, A., Ahmed, S., Saghafinia, A., \& Bahreininejad, A. (2012). Sustainable supplier selection: A ranking model based on fuzzy inference system. Applied Soft Computing, 12(6), 1668-1677.

Ashby, A., Leat, M., \& Hudson-Smith, M. (2012). Making connections: a review of supply chain management and sustainability literature. Supply Chain Management: An International Journal, 17(5), 497-516.

Azadnia, A. H., Saman, M. Z. M., \&Wong, K. Y. (2015). Sustainable supplier selection and order lot-sizing: an integrated multi-objective decision-making process. International Journal of Production Research, 53(2), 383-408.

Bai, C., \& Sarkis, J. (2010). Integrating sustainability into supplier selection with grey system and rough set methodologies. International Journal of Production Economics, 124(1), 252-264.

Behdioglu, S., \& Koca, G. (2017). Green Supply Chain Initiatives In Turkish Automotive Main Industry. Journal of Strategic Research in Social Science, 3(3), 177-188.

Carter, C. R., \& Rogers, D. S. (2008). A framework of sustainable supply chain management: moving toward new theory. International journal of physical distribution \& logistics management, 38(5), 360-387.

Dalalah, D., Hayajneh, M., \& Batieha, F. (2011). A fuzzy multi-criteria decision making model for supplier selection. Expert systems with applications, 38(7), 8384-8391.

Fontaine, C., Haarman, A., \& Schmid, S. (2006). The stakeholder theory. Edlays education, 1, 1-33.

Govindan, K., Khodaverdi, R., \& Jafarian, A. (2013). A fuzzy multi criteria approach for measuring susta- inability performance of a supplier based on triple bottom line approach. Journal of Cleaner production, 47, 345-354.

Govindan, K., Jafarian, A., Khodaverdi, R., \& Devika, K. (2014a). Two-echelon multiple-vehicle locationrouting problem with time windows for optimization of sustainable supply chain network of perishable food. International Journal of Production EconomiCS, 152, 9-28.

Govindan, K., Kaliyan, M., Kannan, D., \& Haq, A. N. (2014b). Barriers analysis for green supply chain management implementation in Indian industries using analytic hierarchy process. International Journal of Production Economics, 147, 555-568.

Hussain, N., Rigoni, U., \& Orij, R. P. (2018). Corporate governance and sustainability performance: Analysis of triple bottom line performance. Journal of Business Ethics, 149(2), 411-432.

Kamali, F. P., Borges, J. A. R., Osseweijer, P., \& Posada, J. A. (2018). Towards social sustainability: Screening potential social and governance issues for biojet fuel supply chains in Brazil. Renewable and Sustainable Energy Reviews, 92, 50-61.

Khan, M., Hussain, M., Gunasekaran, A., Ajmal, M. M., \& Helo, P. T. (2018). Motivators of social sustainability in healthcare supply chains in the UAE-Stakeholder perspective. Sustainable Production and Consumption, 14, 95-104.

Kiris, S. B., \& Borekci, D. Y. (2018). Drivers and barriers for sustainable port management: a triple bottom line approach. Istanbul Gelisim University Journal of Social Sciences, 5(1), 192-220.

Kleindorfer, P. R., Singhal, K., \& Van Wassenhove, L. N. (2005). Sustainable operations management. Production and operations management, 14(4), 482-492.

Koho, M., Nylund, H., Arha, T., \& Torvinen, S. (2011). Towards manufacturing system sustainability assessment: an initial tool and development plans. In Advances in Sustainable Manufacturing (pp. 309314). Springer, Berlin, Heidelberg.

Koska, A., Goksu, N., \&Sunbul, M.B. (2016), Barriers of green supply chaın management ımplementatıon: An applıcatıon in Kipaş paper factory. Journal of Social and Humanities Sciences Research, 6(2), 117-140. 
Kuo, R. J., Wang, Y. C., \& Tien, F. C. (2010). Integration of artificial neural network and MADA methods for green supplier selection. Journal of cleaner production, 18(12), 1161-1170.

Lam, M. L. L. (2011). Successful strategies for sustainability in China and the global market economy. International Journal of Sustainable Strategic Management, 3(1), 73-90.

Lin, R.-J., Tan, K.-H., Geng, Y., (2013). Market demand, green product innovation, and firm performance: evidence from Vietnam motorcycle industry. Journal of Cleaner Production 40, 101-107.

Lund-Thomsen, P., Nadvi, K., Chan, A., Khara, N., \& Xue, H. (2012). Labour in global value chains: Work conditions in football manufacturing in China, India and Pakistan. Development and Change, 43(6), 1211-1237.

Luthra, S., Govindan, K., Kannan, D., Mangla, S.K., Garg, C.P., 2017a. An integrated framework for sustainable supplier selection and evaluation in supply chains. J. Clean. Prod. 140, Part 3, 1686-1698.

Luthra, S., Govindan, K., Mangla, S.K., 2017b. Structural model for sustainable consumption and production adoption - a grey-DEMATEL based approach. Resour. Conserv. and Recycl. 125, 198-207.

Mani, V., Gunasekaran, A., Papadopoulos, T., Hazen, B., \& Dubey, R. (2016). Supply chain social sustainability for developing nations: Evidence from India. Resources, Conservation and Recycling, 111, 42-52.

Moktadir, M. A., Ali, S. M., Rajesh, R., \& Paul, S. K. (2018). Modeling the interrelationships among barriers to sustainable supply chain management in leather industry. Journal of Cleaner Production, 181, 631-651.

Morais, D. O., \& Silvestre, B. S. (2018). Advancing social sustainability in supply chain management: Lessons from multiple case studies in an emerging economy. Journal of Cleaner Production, 199, 222-235.

Muhammad, M. N., \& Cavus, N. (2017). Fuzzy DEMATEL method for identifying LMS evaluation criteria. Procedia computer science, 120, 742-749.

Narayanan, A. E., Sridharan, R., \& Ram Kumar, P. N. (2018). Analyzing the interactions among barriers of sustainable supply chain management practices: A case study. Journal of Manufacturing Technology Management.

Ozcelik, F., \& Oztürk, B. A. (2014). A Research On Barrıers To Sustaınable Supply Chaın Management
And Sustaınable Supplıer Selectıon Crıterıa. Dokuz Eylul University Journal of Graduate School of Social Sciences, 16(2).

Popovic, T., Barbosa-Póvoa, A., Kraslawski, A., \& Carvalho, A. (2018). Quantitative indicators for social sustainability assessment of supply chains. Journal of Cleaner Production, 180, 748-768.

Prakash, C., \& Barua, M. K. (2015). Integration of AHP-TOPSIS method for prioritizing the solutions of reverse logistics adoption to overcome its barriers under fuzzy environment. Journal of Manufacturing Systems, 37, 599-615.

Presley, A., Meade, L., \& Sarkis, J. (2007). A strategic sustainability justification methodology for organizational decisions: a reverse logistics illustration. International Journal of Production Research, 45(18-19), 4595-4620.

Seuring, S., \& Müller, M. (2008). From a literature review to a conceptual framework for sustainable supply chain management. Journal of cleaner production, 16(15), 1699-1710.

Shieh, J. I., Wu, H. H. and Huang, K. K. (2010). A DEMATEL method in identifying key success factors of hospital service quality. Knowledge-Based Systems, 23, 277-282.

Silvestre, B. S. (2015). Sustainable supply chain management in emerging economies: Environmental turbulence, institutional voids and sustainability trajectories. International Journal of Production Economics, 167, 156-169.

Smith, S. L. (1995). Ecologically sustainable development: integrating economics, ecology, and law. Willamette L. Rev., 31, 261.

Tseng, M. L. (2009). A causal and effect decision making model of service quality expectation using grey-fuzzy DEMATEL approach. Expert systems with applications, 36(4), 7738-7748.

Wang, D. H. M., Chen, P. H., Yu, T. H. K., \& Hsiao, C. Y. (2015). The effects of corporate social responsibility on brand equity and firm performance. Journal of business research, 68(11), 2232-2236.

Wu, W. W., \& Lee, Y. T. (2007). Developing global managers' competencies using the fuzzy DEMATEL method. Expert systems with applications, 32(2), 499507. 